\title{
The Impact of Return on Equity (ROE) Dan Debt to Equity Ratio (DER) Toward Change in Profit on the Plantation Company Registered On BEI
}

\author{
Author's Details: \\ Calen ${ }^{1}$, Sunday Ade ${ }^{2}$, Dina Rosmaneliana ${ }^{3}$, Rebecca Evadine ${ }^{4}$ \\ ${ }^{1}$ Polytechnic Of Business Indonesia,Siantar City - ${ }^{2,3,4}$ STIE ITMI Medan, Department Of Management
}

\section{Abstract:}

In general, the objective of each company is to maximalise the value of the company in order to get the maximum profit that the company can survive, do some activities, and create a market segment expansion. The profit gained by the company in future cannot be predicted so that the change in profit from time to time needs to be predicted. The change in a profit of a company can be used as a reference for the investors to determine whether they will buy and sell or save their investigation. The information about the change in profit can be used for the staffs to determine the future of the company a which can influence the staffs' income. This study aims to indicate the impact of return on equity dan debt to equity ratio toward change in profit on the plantation company registered on BEI either partially or simultaneously. This uses hypothesis test with qualitative descriptive study and uses multiple linear regression analysis. The result of this study indicates that return on equity partially influences the change in profit and debt to equity ratio does not influence the change in profit on the plantation company registered on BEI. Return on equity and debt to equity ratio simultaneously influence the change in profit on the plantation company registered on BEI. The result of the coefficient test is 0,149 which means that return on equity and debt to equity ratio influence $14,9 \%$ toward the change in profit and $85,1 \%$ is influenced by other variables, such as dividend payout ratio, size, net profit margin, inflation, etc.

Keywords : Return On Equity, Debt to Equity Ratio, Change in Profit

\section{INTRODUCTION}

In general, the objective of each company is to maximalise the value of the company in order to get the maximum profit that the company can survive, do some activities, and create a market segment expansion. Without any profit, the company cannot make a development. It is the objective of each company. Thus the company must be able to do the operating activities efficiently and effectively so that the company can operate the assets and get better profit. If the company becomes greater, it has to keep developing to follow and fulfill the market needs which fluctuate and compete to get good management. For each company, especially a company which has been already gone public has to make an annual financial report to publish to the society. For a company, the financial report is the important mechanism for the manager to communicate to the investors. In this case, the financial report is the accountable medium of management to the owner. The company profit is needed to make it alive. To gain the profit, the company has to do operational activities which are supported by the resource. Profit is the rise of economic benefit during one accounting period which is in income, assets increment, or duty descent which causes equity increment from the contribution of investment. The profit reflects the increase and decrease in equity from all transactions. To count and predict the profit of a company, it can use accounting ratio, such as return on equity. It makes the accounting ratio be a factor to evaluate the accounting condition of the company, in the past, nowadays, and in the future. Also, the financial ratio is used for an early alert system toward the decrease of the financial condition of a company. The profit gained of a company in the future cannot be predicted, so that the change in profit in the future needs to be predicted. The change in profit in a company can be used as a basis for the investors to determine whether they will buy and sell or save their investment. The information about the change in profit can be used by the staffs to determine the success of the company in the future which can influence their income. The profitability which is related to the financial structure. Theoretically, it is called return on equity (ROE). ROE is used to count the effectivity of a company to earn a profit by its own finance. If the profit is greater, ROE of a company will be higher. The management also needs to evaluate the financial performance per period that it can indicate whether the company will be successful or failed. It is surely useful for the company in the future to do operational activities which need enough fund in order to run well. A company who has less fund will find an additional fund to overcome it. The fund can be gained by inputting new fund of the company owner or borrow it from other company. If the company makes a loan to other company, it will create a debt which caused by the loan. It means that the company 
has already operated financial leverage. If the loan is greater, the leverage will be greater. The risk which has to be faced by the company is greater, because of the loan. Financial leverage will take a disadvantage if the profit gained is smaller than the loan. Thus, return on equity and debt to equity ratio are factors which make a change in profit in the future.

\section{LITERATURE REVIEW}

\section{The Change in Profit}

According to Sunyoto $(2015: 81)$, the change in profit is the increase or decrease in profit from year to year. The profit used is relative profit. The relative rate is used because it is more representative than the absolute profit. According to Harahap (2012 : 310), the increase of profit is counted by subtracting the net profit last year from the net profit this year and divided by the net profit last year. This is the indicator of change in profit below.

$$
\Delta \text { Profit }=\frac{\text { Net profit year } \mathrm{t}-\text { Net profit year } \mathrm{t}-1}{\text { Net profit year } \mathrm{t}-1}
$$

Information :

$\Delta$ Profit $=$ Change in profit

$\mathrm{t} \quad=$ Current berjalan

$\mathrm{t}-1=$ Last period

\section{Return On Equity}

Return on equity is one of the important indicators which is often used by investors to evaluate the level of profitability of a company before investing. It is also called high profit on equity. The ratio examines how wise a company uses some resources to get high profit on equity.

According to Harahap (2012 : 305), return on equity is rentability ratio which indicates the percentage of net profit measured the owners. The ratio used by the investors to view the level of return toward the finance they invest is also called return on equity. Return on equity measures the ability of the company to get profit provided by the shareholder. According to Sartono (2011: 124), this is the indicator of return on equity below.

$$
\text { ROE }=\frac{\text { Net profit after tax }}{\text { Self }- \text { Finance }}
$$

\section{Debt to Equity Ratio}

According to $(2012: 157)$, debt to equity ratio is a ratio used to evaluate the debt by equity. The ratio is identified by comparing the total fund provided by the creditor for the owner of the company. The ratio functions to indicate each self-fund used for the assurance of the debt. For the company, if the ratio becomes greater, it will be better, but if the ratio becomes lower, the fund provided by the owner will be greater. There will be a higher limitation of loan for the borrower if there are loss and risk of finance of the company. According to Sunyoto, et al. (2015 : 75), debt to equity ratio is a measurement which is used to analyse the financial report to show how great the assurance is provided for the creditor. If the ratio is lower, it will be better, because it will be safe to provide liquidity. If the debt to equity ratio is higher, the company will have a higher risk. According to Kasmir (2012 : 158), the formula used to find the dept to equity ratio can use the comparation between the total debt and equity. The indicator is below.

$$
\mathrm{DER}=\frac{\text { Debt }}{\text { Equity }}
$$

\section{METHODOLOGY}

\section{Population and Sample}

According to Sugiyono (2012:80), the population is generalization area containing an object which has quality and characteristic which is determined by the researcher to study and gain the conclusion. In this study, the population used is the plantation company registered on BEI (2010-2014). According to Sugiyono (2012 : 81), the sample is part of characteristic owned by the population. The technique used to gain the 
sample in this study is purposive sampling method which has some criteria. The plantation company is registered on BEI (2012-2017), and it has a complete financial report during the period of observation.

Table 1. Choosing Sample

\begin{tabular}{|l|l|l|}
\hline No. & Information & Total \\
\hline 1. & $\begin{array}{l}\text { Plantation company registered on BEI } \\
(2010-2014)\end{array}$ & 16 \\
\hline 2. & $\begin{array}{l}\text { The company who does not have a } \\
\text { complete financial report during the } \\
\text { observation period }\end{array}$ & $(8)$ \\
\hline The total of companies chosen to be a sample & 8 \\
\hline
\end{tabular}

Based on the criteria, the total of the samples is 10 companies. Thus the total of the sample becomes $8 \times 5$ years $=40$ samples.

Data Analysis Technique

\section{Descriptive Statistics}

The analysis of descriptive statistic is a descriptive analysis which gives information about data gained and does not mean to evaluate the hypothesis.

\section{Classical Assumption Test}

According to Ghozali (2012 : 160), the classical assumption test aims to produce a good regression model. To avoid the mistake in the classical assumption test, the total of samples used has to be free of refraction.

\subsection{Normality Test}

In this study, it uses Kolmogorov Smirnov test. If the significance is more than 0.05 , it means that the data has been distributed ordinarily, but if the significance is less than 0.05 , it means that the data has not been distributed ordinarily.

\subsection{Multicollinearity Test}

According to Ghozali (2012 : 139), a good regression model should not have a correlation among free variables. The next one is the way to detect the existence of multicollinearity in the regression model. The value of R-Squared (R2) which is produced by an estimate of an empirical regression model is high, but many independent variables are not significant which influences the dependence. It analyses correlation matrix of independent variables. If there is a high correlation $(>0.90)$ among independent variables, it means that there is multicollinearity. Based on the value of tolerance and variance inflation factor (VIF), the model of regression is called free of multicollinearity problem, if the tolerance value is more than 0,1 dan, VIF is less than 10 .

\subsection{Heteroscedasticity Test}

According to Ghozali (2012 : 139), heteroscedasticity test aims to evaluate whether, in regression mode, there are different variants from one observation residual to another observation residual which is called homoscedasticity. There is no heteroscedasticity in a good regression model. Heteroscedasticity can be viewed by plot graph between the prediction value of the variable and its residual. If there is a pattern such as some points forming a regular pattern, it indicates that there is heteroscedasticity. If the pattern is not clear and the points spread above or below 0 on the Y-axis, there will not be heteroscedasticity.

\subsection{Autocorrelation Test}

According to Ghozali (2012 : 110), autocorrelation test aims to test whether the linear regression model has a correlation between the disturbing error in period $t$ and the disturbing error in period $t-1$ (previous). To test whether there is an indication of autocorrelation in this study or not, the researcher uses Durbin Watson test. 
Table 2. The Decision of Autocorrelation

\begin{tabular}{|l|l|l|}
\hline Null Hypothesis & Decision & If \\
\hline No positive autocorrelation & Rejected & $0<\mathrm{d}<\mathrm{dl}$ \\
\hline No positive autocorrelation & No decision & $0<\mathrm{d}<\mathrm{du}$ \\
\hline No negative autocorrelation & Rejected & $4-\mathrm{dl}<\mathrm{d}<4$ \\
\hline No negative autocorrelation & No decision & $4-\mathrm{du} \leq \mathrm{d} \leq 4-\mathrm{d}$ \\
\hline $\begin{array}{l}\text { No negative or positive } \\
\text { autocorrelation }\end{array}$ & Not rejected & $\mathrm{Du}<\mathrm{d}<4-\mathrm{du}$ \\
\hline
\end{tabular}

Source : Ghozali (2012: 110)

\section{Multiple Linear Regression Analysis}

According to Ghozali (2012 : 95), the regression analysis is basically a study about dependent variable with one or more independent variable which aims to estimate or predict the average of the population or the average of the dependent variable based on the independent variable. This study uses multiple regression analysis with SPSS 18 for windows. Based on the mechanism of the relationship among variables, the formula is below.

$$
Y=a+b_{1} X_{1}+b_{2} X_{2}+e
$$

Information :

$\begin{array}{ll}\mathrm{X}_{1} & : \text { Return On Equity } \\ \mathrm{X}_{2} & : \text { Debt to Equity Ratio } \\ \mathrm{b}_{1}, \mathrm{~b}_{2} & : \text { Coefficient Parameter of Each Variable } \\ \mathrm{a} & : \text { Constants } \\ \mathrm{e} & : \text { Error Standard }\end{array}$

4. Hypothesis Test

a) Partial Test (T-Test)

Comparing $t$ value and $t$ distribution

If $t_{\text {value }}>t_{\text {distribution, }}$ Ha is accepted dan Ho is rejected.

If $t_{\text {value }}<t_{\text {distribution, }}$ Ha is rejected dan Ho is accepted.

b) Simultant Test (F-Test)

Comparing $\mathrm{t}$ value and $\mathrm{t}$ distribution

If $\mathrm{F}_{\text {value }}>\mathrm{t}_{\text {distribution }}$, Ha is accepted dan Ho is rejected.

If $\mathrm{F}_{\text {value }}<\mathrm{t}_{\text {distribution }}$, Ha is rejected dan Ho is accepted.

c) The coefficient of Determination $\left(\mathrm{R}^{2}\right)$

The coefficient of determination aims to measure the ability of the model to explain the variation of the dependent variable (Ghozali, 2012 : 97). The coefficient of determination is between zero and one. If the value of $\mathrm{R}^{2}$ is small, it means that it is limited to explain the variation of the dependent variable. If the value is close to one, it means that it gives almost all information needed to predict the variation of the dependent variable.

\section{RESULT AND DISCUSSION}

\section{Analyis of Descriptive Statistics}

The analysis of descriptive statistic is a descriptive analysis which gives information about data gained and does not mean to evaluate the hypothesis. This analysis is only used to serve and analyse the data with the calculation in order to make the condition or the characteristic of the data clear. The measurement conducted in this study is mean, standard deviation, maximum and minimum. The result of the analysis of descriptive statistic can is below. 
Table 3. Descriptive Statistics

\begin{tabular}{|l|l|l|l|l|l|}
\hline & $\mathrm{N}$ & Minimum & Maximum & Mean & Std. Deviation \\
\hline PERUBAHAN & 40 & $-2,610$ & 4,050 & 0,23550 & 1,108702 \\
LABA & & & & & \\
ROE & 40 & $-0,120$ & 0,530 &, 15725 & 0,122349 \\
DER & 40 & 0,160 & 3,200 & 1,10375 & 0,767669 \\
Valid N (listwise) & 40 & & & & \\
\hline
\end{tabular}

Source : Output of SPSS

Based on the result of the analysis of descriptive statistic, it gains some conclusions.

a) The minimum value of the change in profit in PT. UNSP Tbk. (2012) is -2,610 and the maximum value in PT. TBLA Tbk (2014) is 4,050. The average is 0,23550 , and the standard deviation is 1,108702 . The observation is conducted 40 times.

b) The minimum value of return on equity in PT. TBLA Tbk (2010) is -0,120 and the maximum value in PT. UNSP Tbk (2013) is 0,530. The average is 0,15725 , and the standard deviation is 0,122349 . The observation is conducted 40 times.

c) The minimum value of debt to equity in PT. LSIP Tbk (2011) is 0,160 and the maximum value in PT. UNSP Tbk (2014) is 3,200. The average is 1,10375 , and the standard deviation is 0,767669 . The observation is conducted 40 times.

2. Classical AssumptionTest

2.1 Normality Test

In this study, the writer uses Kolmogorov Smirnov test. The result of normality test is below.

Table 4. The Result of Normality Test

One-Sample Kolmogorov-Smirnov Test

\begin{tabular}{|c|c|c|}
\hline & & Unstandardized Residual \\
\hline $\begin{array}{l}\mathrm{N} \\
\text { Normal Parameters }\end{array}$ & $\begin{array}{l}\text { Mean } \\
\text { Std. Deviation }\end{array}$ & $\begin{array}{l}40 \\
, 0000000 \\
, 99596280\end{array}$ \\
\hline Extren & eAbsolute & 179 \\
\hline Differences & $\begin{array}{l}\text { Positive } \\
\text { Negative }\end{array}$ & $\begin{array}{l}179 \\
-, 165\end{array}$ \\
\hline $\begin{array}{l}\text { Kolmogorov-Smirnov } \\
\text { Asymp. Sig. (2-tailed) }\end{array}$ & & $\begin{array}{l}1,134 \\
153\end{array}$ \\
\hline
\end{tabular}

a. Test distribution is Normal.

b. Calculated from data.

Source : Output of SPSS

The result of normality on table 4.2 indicates that the value of kolmogrov-smirnov is 0,153 . It indicates the data is distributed ordinarily because the significance is more than 0,05 .

2.2 Multicollinearity Test

Multicollinearity test aims to test whether the regression model is found among free variables. ), a good regression model should not have a correlation among free variables. The next one is the way to detect the existence of multicollinearity in the regression model. The value of R-Squared (R2) which is produced by an estimate of an empirical regression model is high, but many independent variables are not significant which influences the dependence. It analyses correlation matrix of independent variables. If there is a high correlation (> 0.90) among independent variables, it means that there is multicollinearity. Based on the value of tolerance and variance inflation factor (VIF), the model of regression is called free of multicollinearity problem, if the tolerance value is more than 0,1 dan, VIF is less than 10 . The result of multicollinearity test is below.

Table 5. The Result of Multicollinearity Test 


\begin{tabular}{|ll|l|l|}
\hline \multirow{2}{*}{ Model } & \multicolumn{2}{|c|}{ Collinearity Statistics } \\
\cline { 3 - 4 } & & Tolerance & VIF \\
\hline 1 & (Constant) & & \\
& ROE &, 927 & 1,078 \\
& DER &, 927 & 1,078 \\
\hline
\end{tabular}

a.Dependent Variable : CHANGE IN PROFIT

Source : Output of SPSS

Based on table 5, it indicates that all free variables have tolerance value more than 0,1 and the VIF value os less than 10 . Thus, in this study, there is not any multicollinearity problem.

2.3 Heteroscedasticity Test

Heteroscedasticity test aims to evaluate whether, in regression mode, there are different variants from one observation residual to another observation residual which is called homoscedasticity. There is no heteroscedasticity in a good regression model. Heteroscedasticity can be viewed by plot graph between the prediction value of the variable and its residual. If there is a pattern such as some points forming a regular pattern, it indicates that there is heteroscedasticity. If the pattern is not clear and the points spread above or below 0 on the Y-axis, there will not be heteroscedasticity. The heteroscedasticity test in this study is conducted by viewing the scatter plot. The result of heteroscedasticity test is on figure 1 .

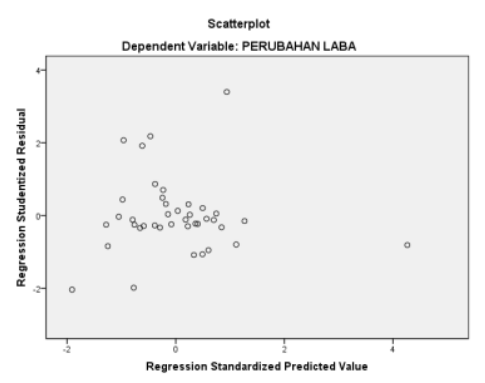

Figure 1. The result of Heteroscedasticity Test

\section{Source : Output of SPSS}

Based on the graphic of scatter plot above, the points spread randomly and spread either below or above 0 on the $\mathrm{Y}$-axis. Thus it can conclude that there is no indication of heteroscedasticity on the regression model used.

\subsection{Autocorrelation Test}

Autocorrelation test aims to test whether the linear regression model has a correlation between the disturbing error in period $\mathrm{t}$ and the disturbing error in period $\mathrm{t}-1$ (previous). To test whether there is an indication of autocorrelation in this study or not, the researcher uses Durbin Watson test. The result of autocorrelation test is in table 6 .

Table 6 The Result of Autocorrelation Test (Durbin Watson Test)

\begin{tabular}{|l|l|l|l|l|l|l|}
\hline Model & $R$ & $R$ Square & $\begin{array}{l}\text { Adjusted } \\
\text { Square }\end{array}$ & $\begin{array}{l}\text { Std. The error } \\
\text { of } \\
\text { Estimate }\end{array}$ & $\begin{array}{l}\text { Durbin- } \\
\text { Watson }\end{array}$ \\
\hline 1 &, $439^{\mathrm{a}}$ & 193 &, 149 & 1,022526 & 1,763 \\
\hline
\end{tabular}

a. Predictors : (Constant), DER, ROE

b. Dependent Variable : CHANGE IN PROFIT

Source : Output of SPSS

Based on table 4.4 above, it indicates that the value of DW gained by the test is 1,763 . Based on the table, the value for the 40 samples and 2 independent variables $(\mathrm{k}=2)$ are $\mathrm{d}=13908$ and $\mathrm{du}=1,6000$. Thus, $4-\mathrm{dI}=2,6092$ and $4-\mathrm{du}=2,400$. It can be conclude that DW is located between the value of du and 4-du $(1,3908<1,763<2,4000)$.

3. Multiple Linear Regression Analysis

The regression analysis is basically a study about dependent variable with one or more independent 
variable which aims to estimate or predict the average of the population or the average of the dependent variable based on the independent variable. Based on the result of data processing using SPSS 18 for windows, it gains some results which are written in table 7.

Table 7. The Result of Multiple Regression Analysis

\begin{tabular}{|c|c|c|c|c|c|c|}
\hline \multirow{2}{*}{\multicolumn{2}{|c|}{ Model }} & \multicolumn{2}{|c|}{$\begin{array}{l}\text { Unstandardized } \\
\text { Coefficients }\end{array}$} & \multirow{2}{*}{\begin{tabular}{|l} 
Standardized \\
Coefficients \\
Beta \\
\end{tabular}} & \multirow[b]{2}{*}{$\mathrm{t}$} & \multirow[b]{2}{*}{ Sig. } \\
\hline & & B & Std. Error & & & \\
\hline \multirow[t]{3}{*}{1} & (Constant) &,- 818 & ,403 & & $-2,031$ &, 050 \\
\hline & ROE & 3,798 & 1,390 &, 419 & 2,733 &, 010 \\
\hline & DER & 414 &, 221 &, 286 & 1,868 &, 070 \\
\hline
\end{tabular}

a. Dependent Variable : CHANGE IN PROFIT

Source : Output of SPSS

Based on table 7 on the column of unstandardized coefficient part B, it gains the multiple linear regression models below.

Change in profit $=-0,818+3,798 \mathrm{ROE}+0,414 \mathrm{DER}+\mathrm{e}$

The next one is the explanation of the coefficients of multiple linear regression . The constants are $-0,818$. It means that if ROE and DER are zero, the change in profit on the plantation company will get a negative value. It is 0,818 . The variable of ROE is 3,798. It means that if ROE increases, the change in profit will be greater. It is 3,798. The assumption of other independent variable is constant. The variable of DER is 0,414. It means that if DER increases, the change in profit will be greater. It is 0,414 . $T$ The assumption of other independent variable is constant.

\section{Hypothesis Test}

\subsection{Simultant Test (F-Test)}

To indicate how far are the variables, the simultant can explain the bound variable. The test is conducted by comparing the value of probability on the table analisys of variance. The value of probability is 0,05 . If the value of probability is more than 0,05 , Ho is rejected, and Ha is accepted. It means that the free variable influences the bound variable. If the probability is less than 0,05 , Ho is accepted. It means that the free variable does not influence the bound variable. The result of test simultaneously is on the table.

Table 8 The Result of Simultant Test (F)

\begin{tabular}{|ll|ll|l|l|l|l|}
\hline Model & & Sum & of & & & \\
& & Squares & df & Mean Square & F & Sig. \\
\hline 1 & Regression & 9,254 & 2 & 4,627 & 4,425 &, $019^{\text {a }}$ \\
& Residual & 38,686 & 37 & 1,046 & & \\
& Total & 47,940 & 39 & & & \\
\hline
\end{tabular}

a. Predictors: (Constant), DER, ROE

b. Dependent Variable: CHANGE IN PROFIT

\section{Source : Output of SPSS}

Based on the ANOVA test, the $F_{\text {value }}$ is 4,425 and $F_{\text {distribution }}$ is $3,25(13,280>3,25)$. It means that ROE and DER simultaneously influence the change in profit. This result is supported by the value of significance which is $0,019(<0,05)$.

\subsection{Partial Test (T-Test)}

To test the coefficient of partial regression, each is a free variable. The decision is based on the comparation of probability value which the significance is $5 \%$. If the value of probability of each free variable is more than 0,05 , Ho is rejected, and $\mathrm{Ha}$ is accepted. It means that the free variable influences the vound variable. If the value of probability of each free variable is less than 0,05 , Ho is accepted, and Ha is rejected. It means that the free variable cannot explain the bound variable individually. The result of test partially is in table 4.7 .

Table 9 The Result of Partial Test (t) 


\begin{tabular}{|c|c|c|c|c|c|c|}
\hline \multirow{2}{*}{\multicolumn{2}{|c|}{ Model }} & \multicolumn{2}{|c|}{$\begin{array}{l}\text { Unstandardized } \\
\text { Coefficients }\end{array}$} & \multirow{2}{*}{\begin{tabular}{|l} 
Standardized \\
Coefficients \\
Beta \\
\end{tabular}} & \multirow[b]{2}{*}{ It } & \multirow[b]{2}{*}{ Sig. } \\
\hline & & $\mathrm{B}$ & Std. Error & & & \\
\hline \multirow[t]{3}{*}{1} & (Constant) &,- 818 &, 403 & & $-2,031$ &, 050 \\
\hline & ROE & 3,798 & 1,390 &, 419 & 2,733 &, 010 \\
\hline & DER &, 414 & 221 &, 286 & 1,868 &, 070 \\
\hline
\end{tabular}

a. Dependent Variable : CHANGE IN PROFIT

Source : Output of SPSS

Based on table 9 about coefficient of regression above, it gains some conclusions. $\mathrm{T}_{\text {value }}$ of ROE is 2,733 and $t_{\text {distribution }}$ is $2,03(2,733>2,03)$. It indicates that the variable is significant because $t_{v a l u e}>t_{\text {distribution. }}$. The significance is 0,010 (below 0,05). It indicates the variable of ROE partially influence the change in profit. $\mathrm{T}_{\text {value }}$ of DER is 1,868 and $\mathrm{t}_{\text {distribution }}$ is $2,03(1,868<2,03)$. It means that the variable is not significant

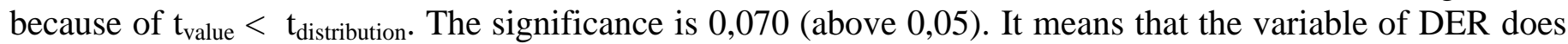
not influence the change in profit partially.

\subsection{Analysis of Coefficient of Determination $\left(R^{2}\right)$}

The coefficient of determination aims to measure the ability of mode in explaining the variance of the dependent variable. The value of the coefficient of determination is between zero and one. If $\mathrm{R}^{2}$ is small, the ability of independent variables in explaining the variance of a dependent variable is limited. The value which is close to one means that the independent variables give almost all information needed to predict the variance of the dependent variable. The result of the coefficient of determination iso the table.

Table 10. The Result of Coefficient of Determination

\begin{tabular}{|c|c|c|c|c|c|}
\hline Model & $\mathrm{R}$ & R Square & $\begin{array}{l}\text { Adjusted } \\
\text { Square }\end{array}$ & R $\begin{array}{l}\text { Std. The } \\
\text { of } \\
\text { Estimate }\end{array}$ & \begin{tabular}{l|l} 
rror & \\
the & Durbin- \\
Watson
\end{tabular} \\
\hline 1 &, $439^{\mathrm{a}}$ &, 193 &, 149 & 1,022526 & 1,763 \\
\hline
\end{tabular}

a. Predictors: (Constant), DER, ROE

b. Dependent Variable: CHANGE IN PROFIT

Source : Output of SPSS

Based on table 10, the value of adjusted $\mathrm{R}$ square is 0,149 containing the influences of independent value (return on equity and debt to equity ratio) toward dependent variable. The change in profit is $14,9 \%$, and the rest of it is $85,1 \%(100 \%-14,9 \%)$ which is influenced by another variable out of model tested in this study.

\section{The Discussion of Study Result}

Based on the result of the t-test, it indicates the influence of return on equity and debt to equity ratio partially toward the change in profit.

\section{The Impact of Return On Equity toward the Change in Profit}

The result of the study indicates that return on equity has a significant and positive influence toward the change in profit on the plantation company registered on BEI (2010-2014). The result of the study is consistent with the result of a study conducted by Suprihatmi and Wahyudin (2003) and Kusuma (2014).

Return on equity is the net profit after tax which is divided by the finance. If the profit of the company increases, it will influence the change in profit in the future. Based on the result of the study the hypothesis 1 states that return on equity influencing the change in profit on the plantation company registered on BEI is accepted.

\section{The Impact of Debt to Equity Ratio toward the Change in Profit}

The result of the study indicates that debt to equity ratio has no a significant and positive influence toward the change in profit on the plantation company registered on BEI (2010-2014). The result of the study is consistent to the result of a study conducted by Suprihatmi and Wahyudin (2003) and Kusuma (2014), but it is not consistent to the result of a study conducted by Sinaga (2010). Debt to equity ratio does not influence the change in profit because there is no efficiency from the company to optimalise the selffinance to assurance all the company dept. based on the result of the study, the hypothesis 2 which states debt to equity ratio influences the change in profit on the plantation company registered on BEI is rejected. 
Based on f-test, it indicates that return on equity dan debt to equity ratio influence the change in profit on the plantation company registered on BEI. Based the result of the study, the hypothesis 3 which states that return on equity and debt to equity ratio influences the change in profit on the plantation company registered on BEI is accepted. The value of adjusted $\mathrm{R}$ square is 0,149 which explain that the independent variable (return on equity dan debt to equity ratio) toward dependent variable (change in profit) is $14,9 \%$ and the rest of it is $85,1 \%(100 \%-14,9 \%)$ which is influenced by another variable out of the model tested in this study, such as dividend payout ratio, size, net profit margin, inflation, etc.

\section{Conclusion}

Based on the result of data analysis and discussion which has been stated in chapter IV, it gains some conclusions. Based on the result of the test, return on equity partially influences the change in profit in plantation company registered on BEI which $t_{\text {value }}$ is 2,733 and $t_{\text {distribution }}$ is $2,03\left(t_{\text {value }}>t_{\text {distribution }}\right)$. The value of significance is 0,010 (below 0,05). Based on the result of the test, debt to equity ratio has no a significant and positive influence toward the change in profit on the plantation company registered in BEI which $t_{\text {value }}$ is 1,868 and $t_{\text {distribution }}$ is 2,03 ( $t_{\text {value }}<t_{\text {distribution }}$ ). The value of significance is 0,070 (above 0,05). Based on $f$ test, it indicates that retun on equity and debt to equity ratio simultaneously influences the change in profit on the plantation company registered on BEI which $f_{\text {value }}$ is 4,425 and $f_{\text {distribution }}$ is 3,25 (4,425 > 3,25). The value of significance is 0,019 (below 0,05). The result of the coefficient of determination indicates that the value of adjusted $R$ square is 0,149. It means that the influence of independent variable (return on equity and debt to equity ratio) toward the change of dependent variable (change in profit) is $14,9 \%$ and the rest of it is $85,1 \%(100 \%-14,9 \%)$. It is influenced by another variable out of the model tested in this study.

\section{REFERENCE}

i. Angkoso, Nandi 2010. Akuntansi Lanjutan. Penerbit FE : Yogyakarta

ii. Brigham, Eugene F dan Houston, 2010. Fundamental of Financial Management : Dasar-Dasar Manajemen Keuangan Edisi 10. Salemba Empat : Jakarta

iii. Fahmi, Irham, 2009. Teori Portofolio dan Analisis Investasi. Teori dan Soal Jawab. CV. Alfabeta : Yogyakarta.

iv. Fahmi, Irham, 2012. Analisis Kinerja Keuangan, Cetakan Kesatu, Penerbit CV. Alfabeta : Bandung

v. Ghozali, Imam, 2012. Aplikasi Analisis Multivariate dengan Program SPSS. Badan Penerbit Universitas Diponegoro : Semarang

vi. Harahap, Sofyan Syafri. 2012. Analisa Krisis Atas Laporan Keuangan. PT Raja Grafindo Persada : Jakarta vii. Jogiyanto, H, M. 2009. Teori Portofolio dan Analisis Investasi, Edisi Ketiga BPFE : Yogyakarta viii. Kasmir, 2012. Analisis Laporan Keuangan, Cetakan Kelima. Penerbit Rajawali Pers : Jakarta.

ix. Kusuma, Winnie, 2014. Pengaruh Rasio Keuangan Terhadap Perubahan Laba Pada Perusahaan Property Dan Real Estate yang Listing di Bursa Efek Indonesia. Skripsi, STIE Harapan : Medan.

x. Mulyadi, 2010. Akuntansi Manajemen : Konsep, Manfaat dan Rekayasa, Edisi Ketiga. Salemba Empat : Jakarta

xi. Munawir. 2007. Analisis Laporan Keuangan. Liberty: Yogyakarta.

xii. Purnawati, Lina. 2005. Kemampuan Rasio Keuangan Dalam Memprediksi Perubahan Laba. (Online), (HTTP://www.pdf-finder .com/kemampuan-rasio-keuangan-dalam-memprediksi-peruahan-laba.html.

xiii. Rosalina, Sari. 2012. Pengaruh Kompetensi dan Independensi Terhadap Kualitas Audit. Jurnal Akuntansi, Vol.1 No.2 (Februari).

xiv. Sartono, Agus, 2011. Manajemen Keuangan (Teori dan Aplikasi). BPFE : Yogyakarta

xv. Sinaga, Rahmawaty, 2010. Analisis Rasio Keuangan Dalam Memprediksi Pertumbuhan Laba pada Perusahaan Property dan Real Estate yang Terdaftar di BEI tahun 2006-2008. Skripsi, Universitas Sumatera Utara : Medan

xvi. Suwardjono. 2008. Teori Akuntansi : Perekayasaan Pelaporan Keuangan. BPFE : Yogyakarta xvii. $\quad$ Sugiyono, 2012. Metode Penelitian Bisnis. CV. Alfabeta : Bandung.

xviii. $\quad$ Sunyoto, Danang, dkk, 2015. Manajemen Keuangan untuk Perusahaan, Cetakan Pertama. Penerbit CAPS : Yogyakarta

xix. Suprihatmi dan Wahyuddin. 2003. Pengaruh Rasio Keuangan Terhadap Kemampuan Memprediksi Perubahan Laba Pada Perusahaan-Perusahaan Manufaktur Yang Terdaftar di Bursa Efek Jakarta. Jurnal Manajemen DAya Saing. Vol.4 No.2

xx. Widjayanti, FEB Tri dan Sutaryo. 2012. Pengaruh Corporate Social Responsibility terhadap Kinerja

Keuangan Perusahaan. Simposium Nasional Akunansi XIV : Aceh.

xxi. www.idx.co.id 